\title{
Compositional Variation of Eudialyte-Group Minerals from the Lovozero and Ilímaussaq Complexes and on the Origin of Peralkaline Systems
}

\author{
Lia N. Kogarko ${ }^{1, *(D)}$ and Troels F. D. Nielsen ${ }^{2}$ \\ 1 Vernadsky Institute of Geochemistry and Analytical Chemistry, Russian Academy of Sciences, \\ 119991 Moscow, Russia \\ 2 Geological Survey of Denmark and Greenland, Øster Voldgade 10, 1350 Copenhagen, Denmark; tfn@geus.dk \\ * Correspondence: kogarko@geokhi.ru
}

check for updates

Citation: Kogarko, L.N.; Nielsen, T.F.D. Compositional Variation of Eudialyte-Group Minerals from the Lovozero and Ilímaussaq Complexes and on the Origin of Peralkaline Systems. Minerals 2021, 11, 548. https:// doi.org/10.3390/min11060548

Academic Editors: Ramiza

K. Rastsvetaeva and Sergey M. Aksenov

Received: 29 April 2021

Accepted: 18 May 2021

Published: 21 May 2021

Publisher's Note: MDPI stays neutral with regard to jurisdictional claims in published maps and institutional affiliations.

Copyright: (C) 2021 by the authors. Licensee MDPI, Basel, Switzerland. This article is an open access article distributed under the terms and conditions of the Creative Commons Attribution (CC BY) license (https:/ / creativecommons.org/licenses/by/ $4.0 /)$.

\begin{abstract}
The Lovozero complex, Kola peninsula, Russia and the Ilímaussaq complex in Southwest Greenland are the largest known layered peralkaline intrusive complexes. Both host world-class deposits rich in REE and other high-tech elements. Both complexes expose spectacular layering with horizons rich in eudialyte group minerals (EGM). We present a detailed study of the composition and cryptic variations in cumulus EGM from Lovozero and a comparison with EGM from Ilímaussaq to further our understanding of peralkaline magma chambers processes. The geochemical signatures of Lovozero and Ilímaussaq EGM are distinct. In Lovozero EGMs are clearly enriched in $\mathrm{Na}+\mathrm{K}$, $\mathrm{Mn}, \mathrm{Ti}$, Sr and poorer Fe compared to EGM from Ilímaussaq, whereas the contents of $\Sigma$ REE $+\mathrm{Y}$ and $\mathrm{Cl}$ are comparable. Ilímaussaq EGMs are depleted in $\mathrm{Sr}$ and $\mathrm{Eu}$, which points to plagioclase fractionation and an olivine basaltic parent. The absence of negative $\mathrm{Sr}$ and Eu anomalies suggest a melanephelinitic parent for Lovozero. In Lovozero the cumulus EGMs shows decrease in Fe/Mn, $\mathrm{Ti}, \mathrm{Nb}, \mathrm{Sr}$, Ba and all HREE up the magmatic layering, while REE $+\mathrm{Y}$ and $\mathrm{Cl}$ contents increase. In Lovozero EGM spectra show only a weak enrichment in LREE relative to HREE. The data demonstrates a systematic stratigraphic variation in major and trace elements compositions of liquidus EGM in the Eudialyte Complex, the latest and uppermost part of Lovozero. The distribution of elements follows a broadly linear trend. Despite intersample variations, the absence of abrupt changes in the trends suggests continuous crystallization and accumulation in the magma chamber. The crystallization was controlled by elemental distribution between EGM and coexisting melt during gravitational accumulation of crystals and/or mushes in a closed system. A different pattern is noted in the Ilimaussaq Complex. The elemental trends have variable steepness up the magmatic succession especially in the uppermost zones of the Complex. The differences between the two complexes are suggested to be related dynamics of the crystallization and accumulation processes in the magma chambers, such as arrival of new liquidus phases and redistributions by mush melts.
\end{abstract}

Keywords: EGM; Lovozero; Ilímaussaq peralkaline nepheline syenites; EGM evolution

\section{Introduction}

Eudialyte is a valuable resource for high-tech elements including $\mathrm{Zr}$, Hf, and REE. This resource potential of eudialyte group minerals (EGM) has attracted increasing interest in the last decade and new information on the EGM group continue to be added [1-5]. EGM is an accessory mineral in many agpaitic rocks with molar ratios of $\mathrm{Na}+\mathrm{K} / \mathrm{Al}_{2} \mathrm{O}_{3}>1$. EGM is found more than in 100 localities (e.g., Pilansberg, Norra Karr, Pocos de Caldas, Tamazeght), but is only present in high tonnage deposits in the Lovozero (Kola Peninsula) and the Illimaussaq (Greenland) complexes. EGMs are here concentrated in layers with 25-95 vol.\% EGM [6,7].

The aim of this contribution is to use the occurrence and composition of eudialyte group minerals (EGM) to further our understanding of magma chamber differentiation and 
dynamics in layered peralkaline syenite complexes such as the Lovozero Complex, Kola peninsula, Russia and Ilímaussaq complex of South Greenland. Lovozero is the world's largest agpaitic complex and hosts immense resources of high-field strength elements (HFSE) in syenites enriched in loparite or eudialyte. In the Ilímaussaq, the HFSE are in syenites enriched in EGM and steenstrupine. In this study we provided detailed information on composition and cryptic variations in EGM of the Lovozero and a comparison with published information on EGM from the Ilímaussaq [8,9].

The ability to host a large number of elements makes EGMs good indicators and monitors for magmatic evolution in highly alkaline magmas [10,11]. EGM exhibit a broad spectrum of compositions due to the unique mineralogical features [10-13]. The crystal structures of EGM are best compared to a microporous zeolite-like framework with the ability to host a large number of elements. Even the simplified general formula of EGMs reflects the significant complexity of the group, and is given as [N1N2N3N4N5] $]_{3} M 1_{6} M 2_{3} M 3 M 4 Z_{3}$ $\left(\mathrm{Si}_{9} \mathrm{O}_{27}\right)_{2}\left(\mathrm{Si}_{3} \mathrm{O}_{9}\right)_{2} \varnothing_{4-6} \mathrm{X} 1 \mathrm{X} 2$, where $\mathrm{M} 1=\mathrm{Ca}, \mathrm{Mn}^{2+}, \mathrm{REE}, \mathrm{Na}, \mathrm{Sr}, \mathrm{Fe}^{2+} ; \mathrm{M} 2=\mathrm{Fe}^{2+}, \mathrm{Fe}^{3+}, \mathrm{Mn}^{2+}$, $\mathrm{Na}, \mathrm{Zr}^{4+} ; \mathrm{M} 3,4=\mathrm{Si}, \mathrm{Nb}, \mathrm{Ti}, \mathrm{W} ; \mathrm{Z}=\mathrm{Zr}, \mathrm{Ti}, \mathrm{Nb} ; \mathrm{N1}-\mathrm{N} 5=\mathrm{Na}, \mathrm{H}_{3} \mathrm{O}^{+}, \mathrm{K}, \mathrm{Sr}, \mathrm{REE}, \mathrm{Y}, \mathrm{Ba}, \mathrm{Mn}^{2+}$, $\mathrm{Ca}, \mathrm{H}_{2} \mathrm{O} ; \mathrm{X1}, 2=\mathrm{H}_{2} \mathrm{O}, \mathrm{Cl}, \mathrm{F}, \mathrm{OH}^{-}, \mathrm{CO}_{3}{ }^{2-}, \mathrm{SO}_{4}{ }^{2}$. At present EGM includes 29 mineral species as well as their chemical and structural variants $[10,11,13]$. In Lovozero, EGM is dominated by "common" eudialyte (e.g., [14]), with proportions of raslakite $\left(\mathrm{Na}_{15} \mathrm{Ca}_{3} \mathrm{Fe}^{2+} 3\left(\mathrm{Na}, \mathrm{Zr}_{3} \mathrm{Zr}_{3}\right.\right.$ $\left.(\mathrm{Si}, \mathrm{Nb})\left(\mathrm{Si}_{25} \mathrm{O}_{73}\right)\left(\mathrm{OH}, \mathrm{H}_{2} \mathrm{O}\right)_{3}(\mathrm{Cl}, \mathrm{OH})\right)$, taseqite $\left(\mathrm{Na}_{12} \mathrm{Sr}_{3} \mathrm{Ca}_{6} \mathrm{Fe}_{3} \mathrm{Zr}_{3} \mathrm{Nb}\left(\mathrm{Si}_{25} \mathrm{O}_{73}\right) \mathrm{Cl}_{2}\left(\mathrm{O}, \mathrm{OH}, \mathrm{H}_{2} \mathrm{O}\right)_{3}\right)$, and sergevanite $\left.\mathrm{Na}_{15}\left(\mathrm{Ca}_{3} \mathrm{Mn}_{3}\right)\left(\mathrm{Na}_{2} \mathrm{Fe}\right) \mathrm{Zr}_{3}\left(\mathrm{Si}_{26} \mathrm{O}_{72}\right)(\mathrm{OH})_{3} \mathrm{H}_{2} \mathrm{O}\right)$ [1].

It is traditionally assumed that giant layered intrusions and their mineral deposits form due to magmatic gravitational accumulation of crystal or crystal mushes. Studies of $\mathrm{Rb}-\mathrm{Sr}, \mathrm{Sm}-\mathrm{Nd}, \mathrm{U}-\mathrm{Th}-\mathrm{Pb}$, Lu-Hf isotopic systems and of $\mathrm{O}, \mathrm{H}$ [15-17] suggest that peralkaline magmatic systems are closed and inhibit the separation and loss of volatiles and the rare HFSE metals, i.e., REE, $\mathrm{Zr}, \mathrm{Hf}, \mathrm{Nb}$, Ta, Th, U, Sr, Ba to late developed fluid phases [15]. In such systems, element contents in the bulk melt will change, mostly depending on the partition coefficients of elements in the crystallizing liquidus phases. This process would also control compositions of liquidus EGM up through the magmatic layers of the eudialyte complex of Lovozero and in Ilímaussaq unless additional processes affected the distribution of elements needed for EGM crystallization. Distributions controlled solely by fractional crystallization would be reflected in cryptic variation in the compositions of EGM. We demonstrate that Lovozero EGM becomes a liquidus phase after the crystallization of about $85 \mathrm{vol} . \%$ of the intrusion (eudialyte complex) [14] formed layers of cumulus EGM and that cryptic variations suggest a traditional fractional crystallization process for Lovozero, but not in Ilímaussaq which in addition to cumulus processes seems affected by redistribution of elements to its latest formed units $[8,9]$.

\section{Geological Setting}

The Lovozero peralkaline Complex is one of the world's largest layered intrusions of agpaitic nepheline syenite. It is located near the center of the Kola Peninsula in Russia and part of the Devonian Kola ultramafic-alkaline and carbonatitic province (KACP) [15,18]. The Complex has a surface area of $625 \mathrm{~km}^{2}$ and exposes a $2400 \mathrm{~m}$ stratigraphic succession of undersaturated felsic plutonic rocks.

The Complex comprise four units, formed in three distinct intrusive phases $[6,16]$. Phase I (Figure 1) comprise even-grained nepheline syenites, nepheline-nosean syenites and occupy only about 5 vol.\% of the complex. The rocks of Phase II occupy $77 \%$ and are also referred to as the "Differentiated Complex". It is composed of a strongly differentiated and layered succession with a regular alternation between of layers of urtite, juvite, foyaite and aegirine and amphibole lujavrite (for descriptions of these rock types see Gerasimovsky et al. $[19,20])$. The layers range in thickness from a few centimeters to hundreds of meters. The stratigraphic order of the rock types is the same across the complex. The inward dip of the layers decreases toward the center of the complex. Lens-like bodies of poikilitic sodalite syenite are related to the lujavrites. The rocks of Phase II are more alkaline than Phase I (agpaiticy $>1$ ). The main rock-forming minerals are nepheline, microcline, sodalite, aegirine 
and arfvedsonite. The accessory phases are typically enriched in elements such as $\mathrm{Sr}, \mathrm{Zr}$, $\mathrm{Nb}$, Ba and REE, and include EGM, lomonosovite, murmanite, lamprophyllite, villiaumite, loparite, lorenzenite, apatite and titanite. EGM occurs as interstitial and anhedral grains in Phase II rocks. The HFSE potential of Phase II is in conformable layers of loparite.

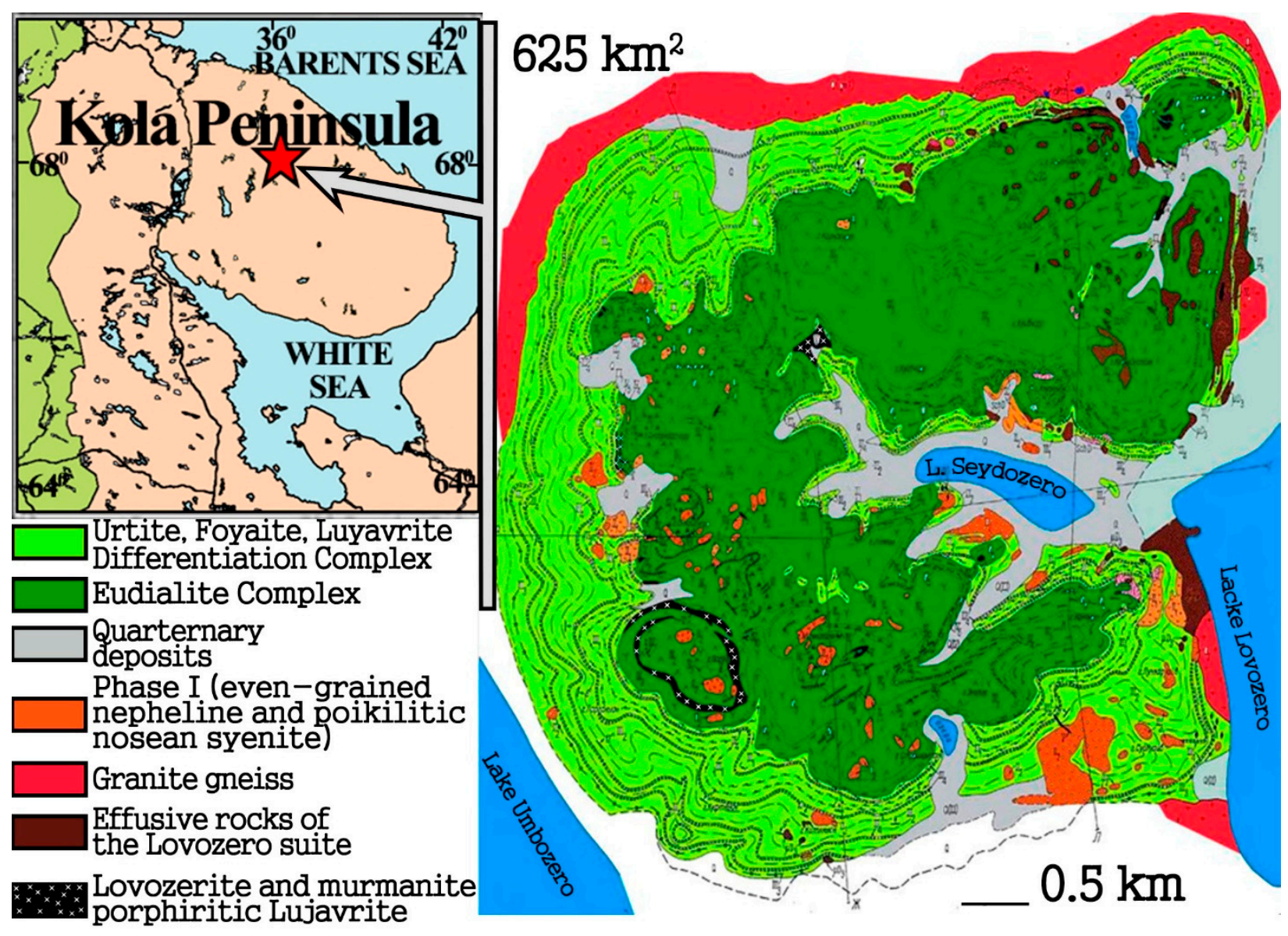

Figure 1. Geological map of the Lovozero complex with inset showing location of Lovozero (star) within the Kola Peninsula.

The rocks of intrusive Phase III comprise a suite of eudialyte lujavrites which cut, and overlie, the upper part of the rocks of Phase II (Phase III is also referred to as "the eudialyte complex").

The dip of the contact between rocks of Phases II and III decreases towards the center of the complex. The rocks of Phase III form the summits of the mountains of the Lovozero complex, and the thickness of this suite reaches $400 \mathrm{~m}$ but, because of erosion, decreases from northwest to southeast.

The rocks of Phase III include leucocratic, mesocratic and melanocratic eudialyte lujavrites, eudialyte foyaite and juvite. The layering is coarser compared to that of Phase II. The main rock-forming minerals of Phase III are nepheline, microcline, aegirine, EGM, lamprophyllite and arfvedsonite. EGM is euhedral in Phase III, which is a fundamental difference to EGM of lujavrites of Phase II. The common accessory minerals of Phase III are lomonosovite, murmanite, loparite, lovozerite, pyrochlore and sodalite. Some horizons defined as eudialyte ore contain $25 \%$ and up to 95 vol.\% of EGM. They are confined to the upper zone of the Phase III.

Bodies of porphyritic lujavrite are found at the contact to Phase II. They are suggested to be partly quenched varieties of eudialyte lujavrite. Late melts of Phase III form intrusive veins of porphyritic lujavrite in Phases I, II and III rocks. They are up to several kilometers in length and up to $50 \mathrm{~m}$ wide, and have phenocrysts of nepheline, microcline, aegirine, 
amphibole, lamprophylite, murmanite, and EGM in a groundmass of the same paragenesis. Poikilitic sodalite syenite and tawite (sodalite-rich rocks with some aegirine and minor nepheline, alkali feldspar and eudialyte) form equidimensional, sharply defined bodies some meters across in Phase II and III lithologies.

\section{Samples and Analytical Method}

The majority of the studied samples were collected from two drill holes (\#178 and \#144). They were drilled through most of the c. 400 thick Phase III. To these were added field hand samples of porphyritic eudialyte lujavrite and porphyritic murmanite lamprophyllite lujavrites. Only cores of well-shaped EGM grains were analyzed in order to minimize the influence of rimming and overprinting processes. The EGM analyses were made using Cameca SX50 and CAMECASX 100 electron microprobes with four wavelength-dispersive spectrometers at the Natural History Museum, London, and at Vernadsky Institute, Moscow. Operating conditions were in both cases an accelerating voltage of $15 \mathrm{kV}$ and a $20 \mathrm{nA}$ probe current. A combination of natural minerals, synthetic compounds, and pure metals, which included synthetic $\mathrm{NaNbO}_{3}, \mathrm{SrTiO}_{3}, \mathrm{CaTiO}_{3}, \mathrm{ZrSiO}_{4}$ and individually REE-doped glasses for the major components were used as standards. We also used standards from Smithsonian Institution (USA). Trace element analyses were performed in Frankfurt University, Max Plank Institute in Mainz, Germany, and Vernadsky Institute, using Thermo Scientific Element 2 ICPMS instruments coupled with a Resonetics Resolution M-50 excimer laser. The laser spot size varied from 20 to $60 \mu \mathrm{m}$. NIST glasses and Zircon 91500 were used as standards. The following isotopes were used for determining the abundances of the elements: ${ }^{29} \mathrm{Si},{ }^{45} \mathrm{Sc},{ }^{88} \mathrm{Sr},{ }^{89} \mathrm{Y},{ }^{90} \mathrm{Zr},{ }^{93} \mathrm{Nb},{ }^{137} \mathrm{Ba},{ }^{139} \mathrm{La},{ }^{140} \mathrm{Ce},{ }^{141} \mathrm{Pr}$, ${ }^{146} \mathrm{Nd},{ }^{147} \mathrm{Sm},{ }^{151} \mathrm{Eu},{ }^{157} \mathrm{Gd},{ }^{159} \mathrm{~Tb},{ }^{161} \mathrm{Dy},{ }^{165} \mathrm{Ho},{ }^{167} \mathrm{Er},{ }^{169} \mathrm{Tm},{ }^{172} \mathrm{Yb},{ }^{175} \mathrm{Lu},{ }^{178} \mathrm{Hf},{ }^{181} \mathrm{Ta}$, ${ }^{208} \mathrm{~Pb},{ }^{232} \mathrm{Th},{ }^{55} \mathrm{Mn},{ }^{57} \mathrm{Fe}$, and ${ }^{24} \mathrm{Mg}$. Contents were calculated from relative peak intensities using the PAP-correction.

The compositions of EGM are presented in apfu and ppm depending on the accuracy of the analyses. The full data set includes 700 analyses in 253 samples.

\section{Results and Data Compilations}

\subsection{Cryptic Variations in Lovozero Cumulus EGM}

Elemental contents in EGM of Phase III are shown in Figure 2 relative to the structural depth of the studied samples. Some crystals show complex zoning and for these we show averages. All formulae were calculated based on $(\mathrm{Si}+\mathrm{Zr}+\mathrm{Ti}+\mathrm{Nb}+\mathrm{Hf}+\mathrm{Al})=29$ apfu. The data are consistent with the published information $[3,21]$.

Up through the Phase III, cumulus EGM becomes progressively depleted with Fe from 1.81 to $1.57 \mathrm{apfu}$ and enriched in Mn from 0.74 to $1.08 \mathrm{apfu}$. The $\mathrm{Mn} / \mathrm{Fe}$ ratio increases from 0.41 to 0.68 . $\mathrm{Na}$ and $\mathrm{K}$ in EGM is near constant up the stratigraphy from 16.41 to $16.95 \mathrm{apfu}$ and from 0.23 to $0.22 \mathrm{apfu}$, respectively. Sr and Ba contents in EGM decrease systematically upward from 12,200 to $8050 \mathrm{ppm}$ Sr and from 3400 to $700 \mathrm{ppm}$. Ba. REE + Y, including HREE, increase from 15,200 to 16,100 ppm in EGM from the upper part of Phase III while the sum of HREE gradually decreases.

$\mathrm{Ti}$ and $\mathrm{Nb}$ contents in EGM vary little in Phase III with Ti decreasing from 0.26 to 0.21 apfu and $\mathrm{Nb}$ decreasing from 3400 to $3100 \mathrm{ppm}$. Cl in EGM increases systematically upward from 0.86 to $1.23 \mathrm{apfu}$, while $S$ decreases from 0.13 to $0.07 \mathrm{apfu}$. Contents of $\mathrm{U}$ and Th in EGM are low in our data and not very accurate due to analytical uncertainty, but suggest an upward increase in both elements from 20 to $80 \mathrm{ppm} \mathrm{U}$ and 30 to $70 \mathrm{ppm}$ Th.

\subsection{Data for Comparison between Ilimaussaq and Lovozero}

To allow comparison between EGM in Lovozero and Ilímaussaq we chose to calculate average compositions of EGM in the two complexes. The Lovozero average (Table 1) is based on our data and the average of Ilímaussaq EGM (Table 2) on the supplementary data in [9] providing 20 averages, excluding compositions from hybrid rocks and marginal pegmatites. 

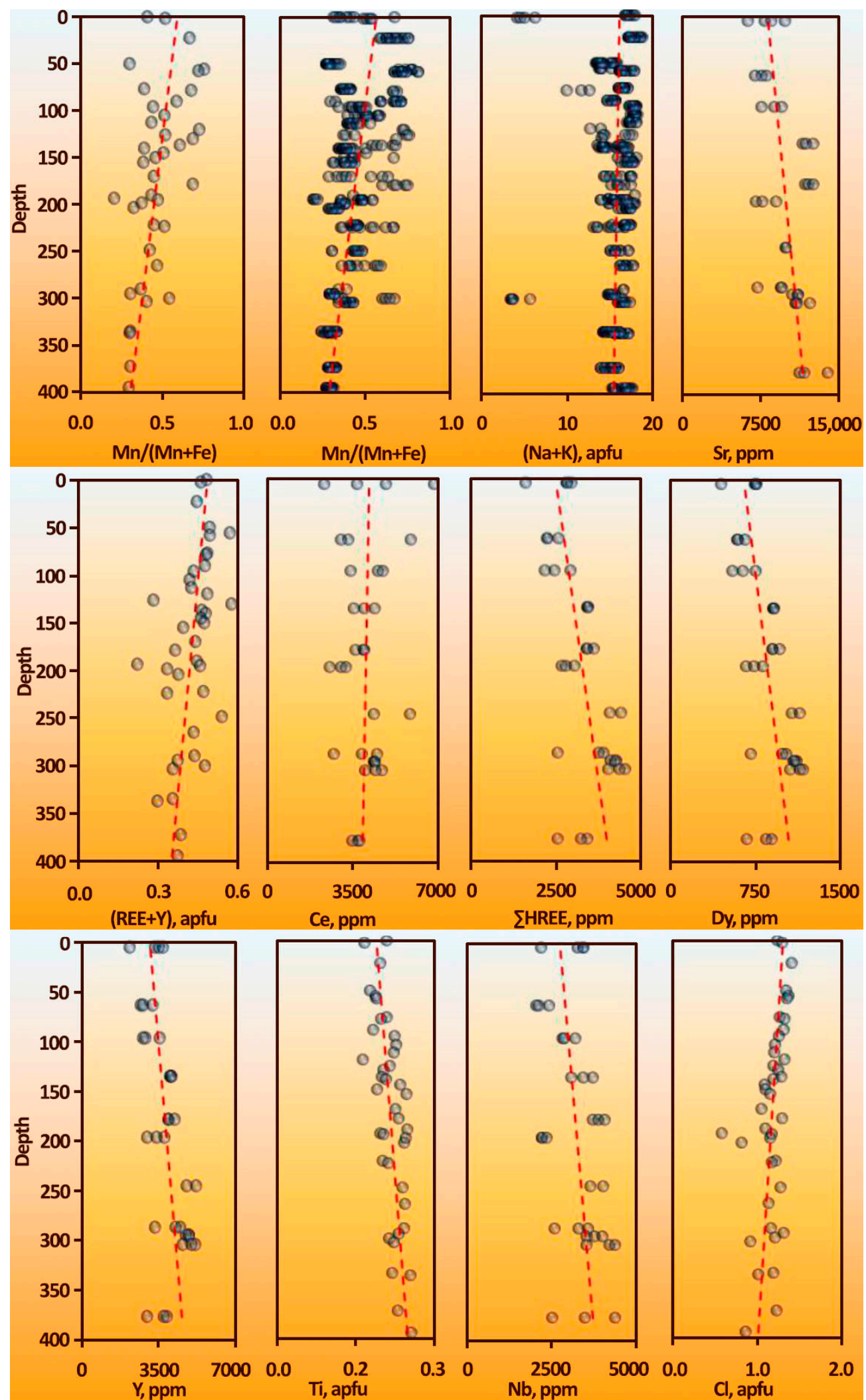

Figure 2. Compositional variations in Lovozero EGM plotted against stratigraphy. The material is collected from drill holes, so 400 m means the deepest part; 0-the top of the section. 
Table 1. Average compositions of EGM in Lovozero rocks.

\begin{tabular}{|c|c|c|c|}
\hline Element & Max & Min & Average \\
\hline \multicolumn{4}{|c|}{ ppm } \\
\hline $\mathrm{Nb}$ & 13,600 & 1900 & 5600 \\
\hline $\mathrm{Sr}$ & 25,600 & 3800 & 13,400 \\
\hline $\mathrm{Ba}$ & 7400 & 90 & 3200 \\
\hline $\mathrm{La}$ & 9300 & 1110 & 3600 \\
\hline $\mathrm{Ce}$ & 25,700 & 2200 & 9000 \\
\hline $\operatorname{Pr}$ & 4400 & 300 & 1600 \\
\hline $\mathrm{Nd}$ & 7800 & 500 & 3300 \\
\hline $\mathrm{Sm}$ & 1300 & 300 & 700 \\
\hline $\mathrm{Eu}$ & 250 & 100 & 200 \\
\hline $\mathrm{Gd}$ & 800 & 300 & 600 \\
\hline $\mathrm{Tb}$ & 150 & 50 & 100 \\
\hline Dy & 850 & 300 & 600 \\
\hline Ho & 200 & 60 & 100 \\
\hline Er & 500 & 200 & 350 \\
\hline $\mathrm{Tm}$ & 70 & 20 & 50 \\
\hline $\mathrm{Yb}$ & 500 & 140 & 300 \\
\hline $\mathrm{Lu}$ & 80 & 20 & 50 \\
\hline$\sum \mathrm{REE}$ & 51,800 & 5500 & 20,500 \\
\hline $\mathrm{Y}$ & 4900 & 1500 & 3200 \\
\hline Th & 70 & 20 & 40 \\
\hline $\mathrm{U}$ & 70 & 30 & 40 \\
\hline \multicolumn{4}{|c|}{ a.p.f.u. } \\
\hline $\mathrm{Na}$ & 18.46 & 2.99 & 15.27 \\
\hline $\mathrm{K}$ & 0.65 & 0.06 & 0.19 \\
\hline $\mathrm{Ca}$ & 6.00 & 2.51 & 4.15 \\
\hline $\mathrm{Fe}$ & 2.68 & 0.33 & 1.42 \\
\hline $\mathrm{Mn}$ & 1.98 & 0.52 & 1.03 \\
\hline $\mathrm{Ti}$ & 0.52 & 0.10 & 0.21 \\
\hline$\sum \mathrm{REE}+\mathrm{Y}$ & 1.43 & 0.12 & 0.43 \\
\hline $\mathrm{Cl}$ & 1.55 & 0.10 & 1.13 \\
\hline
\end{tabular}

Mikhailova et al. [21]; Mikhailova et al. [2]; Wu et al. [22]; Schilling et al. [3]; Kogarko, Nielsen [14].

Table 2. Average compositions of EGM in Ilímaussaq rocks.

\begin{tabular}{cccccc}
\hline Element & Average & Element & Average & Element & Average \\
\hline \multicolumn{7}{c}{} & ppm & & \\
\hline $\mathrm{Nb}$ & 6600 & $\mathrm{Sm}$ & 800 & $\mathrm{Tm}$ & 100 \\
$\mathrm{Sr}$ & 700 & $\mathrm{Eu}$ & 70 & $\mathrm{Yb}$ & 700 \\
$\mathrm{Ba}$ & 700 & $\mathrm{Gd}$ & 800 & $\mathrm{Lu}$ & 90 \\
$\mathrm{La}$ & 4600 & $\mathrm{~Tb}$ & 140 & $\sum \mathrm{REE}$ & 20,200 \\
$\mathrm{Ce}$ & 6300 & $\mathrm{Dy}$ & 1000 & $\mathrm{Y}$ & 5100 \\
$\mathrm{Pr}$ & 900 & $\mathrm{Ho}$ & 200 & $\mathrm{Th}$ & 30 \\
$\mathrm{Nd}$ & 3800 & $\mathrm{Er}$ & 700 & $\mathrm{U}$ & 50 \\
\hline & & a.p.f.u. & & \\
\hline $\mathrm{Na}$ & 13.78 & $\mathrm{Fe}$ & 2.44 & $\mathrm{Nb}$ & 0.20 \\
\hline $\mathrm{K}$ & 0.19 & $\mathrm{Mn}$ & 0.36 & $\sum \mathrm{REE}+\mathrm{Y}$ & 0.54 \\
\hline $\mathrm{Ca}$ & 5.35 & $\mathrm{Ti}$ & 0.02 & $\mathrm{Cl}$ & 1.19
\end{tabular}

Marks et al. [9]; Wu et al. [22]; Pfaff at el. [23]; Borst et al. [8]; Schilling et al. [3].

Average EGM of Ilímaussaq shows an average Fe of 2.44 apfu and 0.36 apfu Mn. In contrast, Lovozero shows Fe average of $1.42 \mathrm{apfu}$, and a Mn average of $1.03 \mathrm{apfu}$. The large difference in the Fe content probably reflects the higher average Fe content in the rocks of the Ilímaussaq intrusion of $10.18 \mathrm{wt} \%$ [6,24] compared to 5.5. $w t \%$ in Lovozero [19]. The average Mn content in Ilímaussaq rocks is only $0.19 \mathrm{wt} \%$ compared to the Lovozero 
rocks- $0.33 \mathrm{wt} \%$. The $\mathrm{Mn} / \mathrm{Fe}$ ratio in Phase III liquidus EGM is therefore 0.73 compared to 0.15 in Ilímaussaq. Although the data shows some scatter, the $\mathrm{Mn} / \mathrm{Fe}$ ratios increase in both complexes with the fractionation of the remaining bulk magmas (Figure 2; see also Figure 3 in [8] and Figure 4 in [9]).

The contents of $\mathrm{Ti}$ and $\mathrm{Nb}$ are low in Lovozero as well as Ilímaussaq EGM. The average for $\mathrm{Ti}$ in Lovozero is $0.22 \mathrm{apfu}$, and the average for $\mathrm{Nb} 4900$ ppm (Table 1). In Ilímaussaq $\mathrm{Ti}$ is much lower with an average $0.02 \mathrm{apfu}$ and $\mathrm{Nb}$ a bit higher with $6600 \mathrm{ppm}$ (Table 2, [3,8,22]).

The average $\mathrm{Na}+\mathrm{K}$ in EGM from Lovozero is 15.46 apfu and only slightly higher than in EGM of Ilímaussaq with 13.97 apfu. $\mathrm{Na}+\mathrm{K}$ remain near constant up the eudialyte complex in Lovozero and through the Ilímaussaq stratigraphy, probably due to control by the proportion of the main liquidus phases comprising nepheline, microcline, aegirine, amphibole near the eutectic of nepheline syenites [15,25].

The content of $\mathrm{Sr}$ and Ba in Ilímaussaq EGM is very low ( $<0.1 \mathrm{apfu})$ while Lovozero EGM is enriched in these elements with averages for Sr of 9100 and for Ba of 1300 ppm. $\mathrm{Sr}$ and $\mathrm{Ba}$ in cumulus Lovozero EGM decrease systematically upward from 12,200 to 8050 ppm and from 3400 to 700, respectively (Figure 2).

The average of total REE $+\mathrm{Y}$ in EGM from Ilímaussaq and Lovozero are slightly different with an average of 0.43 apfu in Lovozero (Table 1) and 0.54 apfu in Ilímaussaq [9] (Table 2). Note should be taken that the Ilímaussaq apfu is based on La, Ce and $\mathrm{Nd}$ and that the real REE + Y number would be higher. A gradual decrease in HREE relative to LREE upward in Lovozero EGM (Figure 2) suggests a slightly elevated partition of HREE over LREE in minerals crystallized from the remaining bulk liquid.

The average content of $\mathrm{Cl}$ in Lovozero and Ilímaussaq was compared with 1.12 and $1.2 \mathrm{apfu}$, respectively. S occupy the same structural position as $\mathrm{Cl}$ in eudialyte [11]. The growth of $\mathrm{Cl}$ content in cumulus Lovozero EGM (from 0.86 to $1.23 \mathrm{apfu}$ ) and in $\mathrm{Cl} / \mathrm{S}$ reflects the general differentiation trend in Lovozero. In EGM of Phase II the $\mathrm{Cl} / \mathrm{S}$ ratio is 0.16 and increases to 0.36 in the upper part of Phase III. In Ilímaussaq EGM, Cl noticeably decreases with fractionation and especially in the latest crystallized units. Decrease in $\mathrm{Cl}$ is seen as the consequence of crystallization of Cl-bearing sodalite and EGM [8,26].The U average content of 40 ppm in the Lovozero EGM is slightly lower in comparison with 50 ppm in Ilímaussaq EGM. The Th average is up to $30 \mathrm{ppm}$ in both Complexes. [3,8,22,23]. There is an increase in the average contents of $U$ and Th in Lovozero cumulus EGM of Phase III, likely due to a sharp decrease in the crystallization field of loparite $[19,27]$.

\subsection{REE and Trace Elements Spectra}

The normalized REE trace elements highlight differences between EGM in Ilímaussaq and Lovozero. All chondrite normalized REE spectra of Lovozero EGM lack a negative Eu anomaly and contain high Sr contents (Figure 3, Table 1), whereas all EGMs from Ilímaussaq have a clear negative Eu anomaly and very low Sr contents. In Figure 3A the slope of the REE spectra of Lovozero EGMs is gentle with highest values for the LREE. The average $\mathrm{Ce} / \mathrm{Y}$ ratio is 1.08 . In Ilímaussaq the spectra show more variation (Figure $3 \mathrm{C}$ ). The average for HREE is almost flat until the deep Eu anomaly and a steepening in LREE trend. The average Ce/Y ratio is 1.63 in Ilímaussaq EGMs. The normalized trace elements plots (Figure 3B,D) show that the Ilímaussaq EGM are strongly depleted in Sr compared to Lovozero, an observation already made and discussed by [9]. 

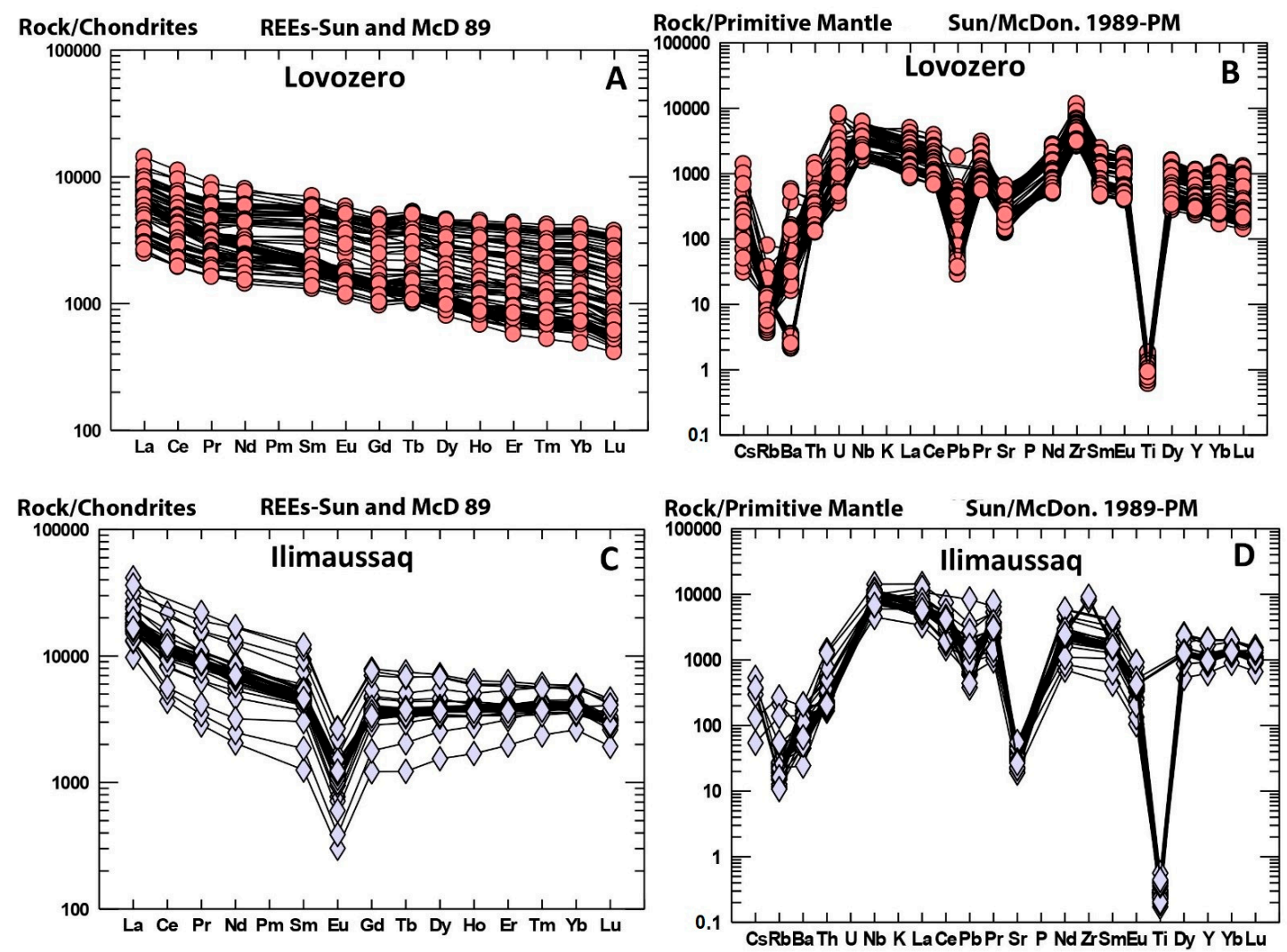

Figure 3. (A) REE Lovozero; (B) spidergram Lovozero; (C) REE Ilímaussaq; (D) spidergram Ilímaussaq [3,8,23].

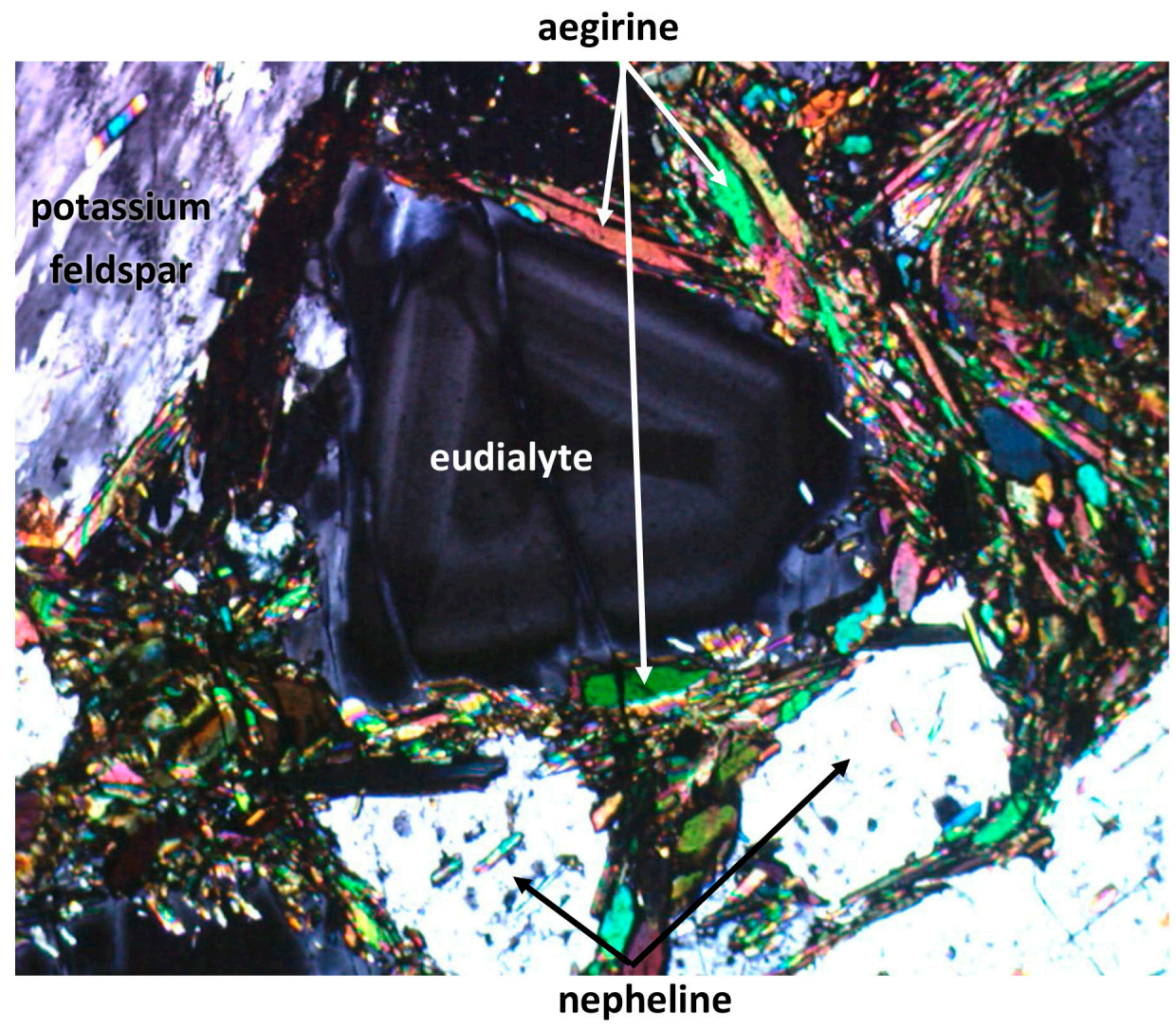

Figure 4. Association of liquidus minerals EGM, nepheline, microcline, aegirine (field of view $1.2 \mathrm{~mm}$ ). 


\section{Discussion}

\subsection{EGM as Liquidus Phase in Phase III}

Phase III of Lovozero is characterized by cumulus layers of EGM. Phase III represents the last c. 15 vol.\% of the Lovozero complex. EGM started to crystallize in Phase III as euhedral grains (Figure 4) as part of the liquidus paragenesis and in equilibrium with nepheline, aegirine, microcline, amphibole (e.g., [14] and references therein). EGM accumulated in potential ores in consequence of saturation in the bulk melt with components needed for nucleation of EGM. The compositional variation in EGM in the $400 \mathrm{~m}$ profile in Phase III (Figure 2) therefore records the evolution of the remaining bulk melt and allows comparisons to other EGM crystallizing complexes, such as Ilímaussaq.

We add that primary, crystallized microinclusions in cumulative EGM in eudialyte lujavrites (Figure 5) support that accumulated EGM crystals in Phase III formed on the liquidus. In heating experiments, melt starts to form inside the inclusions at c. $650{ }^{\circ} \mathrm{C}$ and microcline, sodalite, aegirine, lamprophyllite are completely resorbed during gradual heating up to $900{ }^{\circ} \mathrm{C}$. All phases are completely dissolved at $970{ }^{\circ} \mathrm{C}$ and the walls of the inclusion were partly melted [28]. The observed content of $1.2 \mathrm{wt} \% \mathrm{ZrO}_{2}$ in the homogenized melt is very close to the level saturation needed for EGM crystallization in alkaline melt [14].

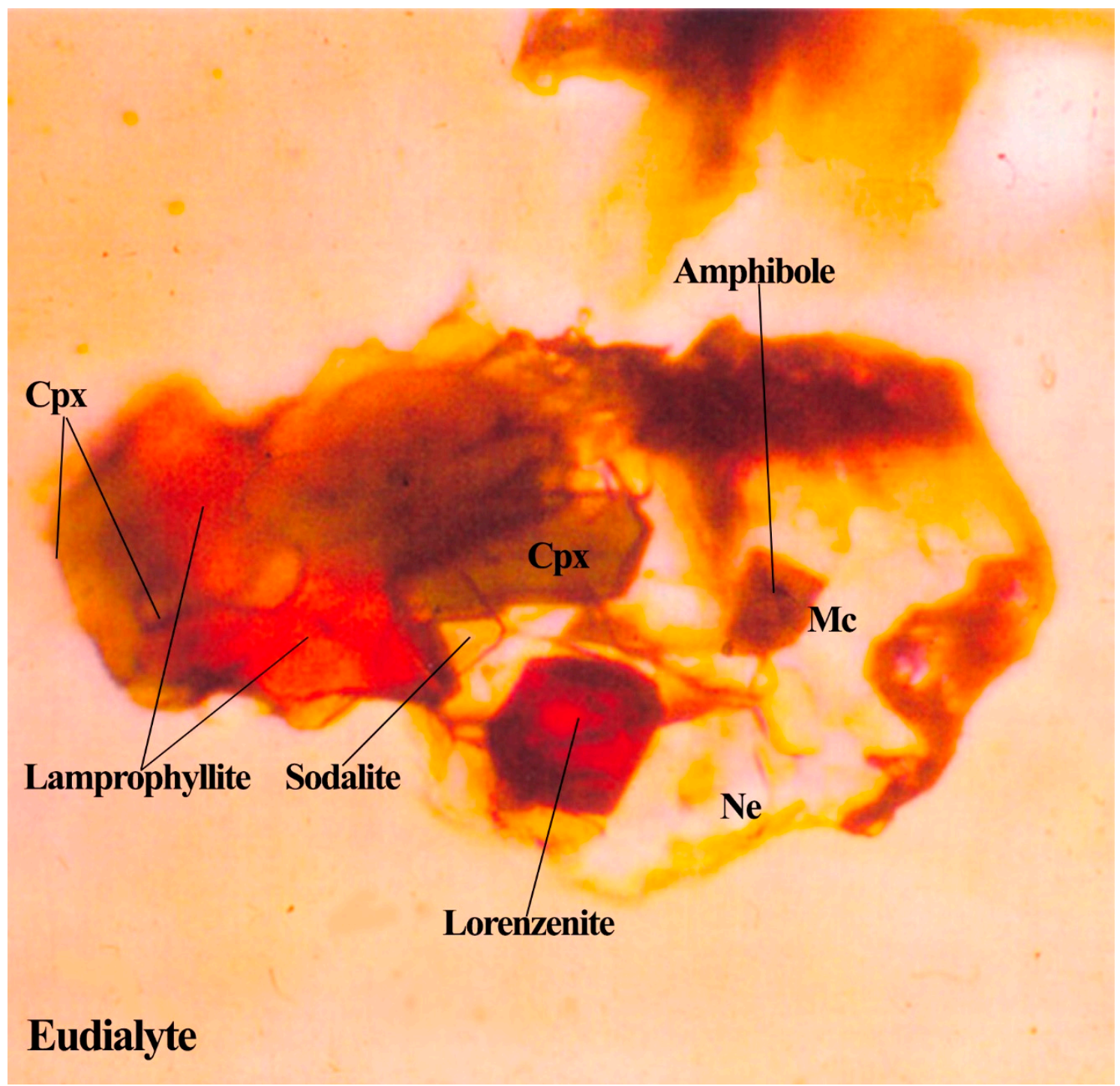

Figure 5. Microinclusions in EGM ore, Phase III, field of view $110 \mu \mathrm{m}$. 
The systematic compositional evolution in EGM in Lovozero conforms with our understanding of EGM as cumulus phase that is separated from bulk magma during the cooling. The EGM crystals were isolated in the mushes or cumulus layers at the floor or roof and avoided re-equilibration. In addition, the very high contents of EGM crystals in some layers point to a physical accumulation process and consequently to convective motion in the magma chamber. We believe that the fractionation of the bulk melt as monitored in cores of EGM crystals up through the Phase III (Figure 2) is best understood as crystallization of EGM during classic convection of the magma and gravitational accumulation of formed crystals.

\subsection{Geochemical Signature of EGM in Lovozero and Ilimaussaq}

The chemical fingerprints of EGM crystallizing magmas are best seen in the substitutions for major elements in EGM. We therefore focus on the minor and trace elements of EGMs in Lovozero and Ilímaussaq. The contents of $\mathrm{Sr}$ and $\mathrm{Ba}$ are high in Lovozero (Table 1) and very low (<0.1 apfu) in Ilímaussaq EGM (Table 2). In both complexes Sr and Ba decrease in content with fractionation. In lovozero we tentatively correlate the decreases with crystallization of lamprophyllite. The proportion of lamprophyllite significantly increases in Phases III, where lamprophyllite forms mushes of very small crystals, especially in the uppermost parts of Figure 6.

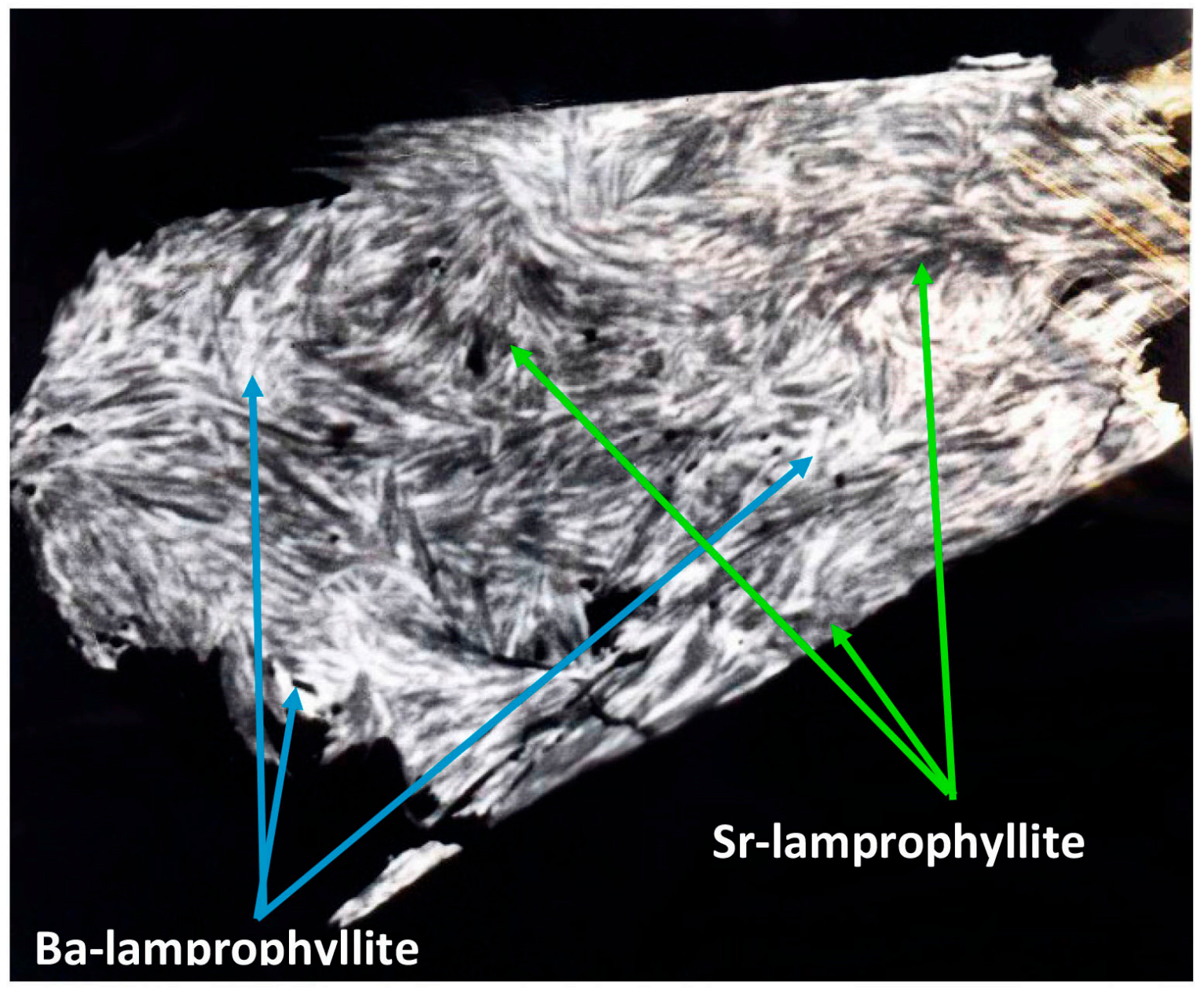

Figure 6. Mush of lamprophyllite (field of view $0.25 \mathrm{~mm}$ ). The mush is represented by a mixture of barium and strontium lamprophyllite. Light crystals-Ba-lamprophyllite; dark crystals-Sr-lamprophyllite.

In Lovozero $\mathrm{Ti}$ and $\mathrm{Nb}$ in EGM decrease with fractionation (Figure 2), most likely due to arrival of liquidus lamprophyllite with up to $29 \mathrm{wt} \% \mathrm{TiO}_{2}$ and murmanite with up 
to $30 \mathrm{wt} \% \mathrm{TiO}_{2}$ and up to $22 \mathrm{wt} \% \mathrm{Nb}_{2} \mathrm{O}_{5}$. The presence of lamprophyllite and murmanite phenocrysts in porphyritic eudialyte lujavrites supports that they are on liquidus in Phase III melt.

In Ilimaussaq the content of $\mathrm{Ti}$ and $\mathrm{Nb}$ decreases upwards [8] until a reversal in the aegirine lujavrites in top of the profile of $[8,9]$ and records a larger compositional spread in the lujavites and the syenites (naujaites) under the roof of the intrusion. The average $\mathrm{Nb}$ content in Ilímaussaq EGM is $6600 \mathrm{ppm}[3,8,22]$. Nb and Ti contents in the uppermost parts of Ilímaussaq are influenced by the crystallization of rinkite that concentrate Ti and $\mathrm{Nb}$ and aenigmatite with Ti of 7-9 $\mathrm{wt} \%[8,9]$.

\subsection{Chemical Composition and Petrogenetic Implications of EGM in the Lovozero and Ilímaussaq Complexes}

Lovozero and Ilímaussaq Complexes expose the spectacular layering of horizons containing EGM. Repetitive model layering and cryptic variation in compositions of liquidus phases are characteristic for layered intrusions and layering caused by fractional crystallization. There are no abrupt changes in the compositional trends of EGM during the differentiation of Phase III in Lovozero (Figure 2) and as suggested above, the main mechanism of layering in Lovozero Phase III was continuous accumulation of crystallization products in the intermittent floor of the magma chamber due to gravitational separation and crystal mush formation in a closed system. Exception was trapping of small crystals of EGM in the roof of the magma chamber [14] in a process similar to that suggested for small apatite crystals in ores of Khibiny complex [29].

Another development is noted in the Ilimaussaq Complex $[8,30]$. The elemental trends are systematic in the layered kakortokites (LLK and TLK) but deviate in aegirine lujavrites and the most evolved part of the intrusion (Figure 6 in Borst et al. [8]) and more evolved lujavrites [26]. This suggests changes either due to new phases on liquidus or, e.g., mixing and reaction with residuals and fluids from compacting mushes. Changes in the partition coefficients of liquidus phases would also affect the composition of EGM. As shown by, e.g., [31,32] the compositions of cumulus phases in layered intrusions can be changed dramatically by subsequent reaction with intercumulus melts and fluids and contribute to the scatter in the evolutionary trends.

\subsection{The Proposed Parental Melts of Lovozero and Ilimaussaq}

The most significant difference between EGM from the two complexes is the distinct negative anomalies in $\mathrm{Sr}$ and Eu in Ilímaussaq EGM. No plagioclase would have been on liquidus during fractional crystallization of parental olivine nephelinites or melanephelinite melts of the KACP. The fractionating phases in the olivine nephelinite/melanephelinite lineages are olivine, melilite and clinopyroxene. They do not concentrate $\mathrm{Eu}$ or Sr due to very low distribution coefficients [33-35]. Nor does nepheline when melts become more evolved (e.g., Larsen [36]). The results also confirm that the oxygen fugacity of Lovozero Complex was very close to the QFM buffer system [37] and EGM mostly contained $\mathrm{Eu}^{3+}$ [38].

In stark contrast, all chondrite normalized REE spectra of Ilímaussaq EGM have a negative Eu anomaly and very low Sr content [9]. Important fractionation of plagioclase is envisaged to have depleted the evolving melt in $\mathrm{Eu}^{2+}$ and Sr. Following and agreeing with [9] the parental melt of the Ilímaussaq complex, at least at some stage, crystallized plagioclase. This suggests that melt(s) of the Ilímaussaq complex formed by fractional crystallization processes from an alkali olivinebasaltic or basanitic parent common throughout the Gardar province [39-42]. It would have plagioclase as the main leucocratic mineral. Although the mineralogy and many other features are common to Lovozero and Ilimaussaq they may have very different parents and evolutionary trends.

The mafic dykes or the Gardar province are transitional basalts with transitional olivine basalt parents. Their lightly increased alkalies may allow the term trachybasalt for the mafic members or at least for those that are close to the critical plane of Siundersaturation [41]. They are Fe-rich and some plot in the basanite field of the total alkalies diagram versus $\mathrm{SiO}_{2}$ (TAS), even though they crystalize plagioclase. Such Fe-rich 
Gardar melts would fractionate to Fe-rich trachyandesite and most likely end up in the undersaturated minima and crystallize monzonites, syenites and eventually small residual volumes of nepheline syenites toward the $\mathrm{SiO}_{2}$-undersaturated minimum. In this light, the origin of the large volume of peralkaline melt in Ilimaussaq complex remains enigmatic.

\section{Conclusions}

1. The petrographic observations show that EGM is an early cumulus mineral in the eudialyte complex (Phase III of Lovozero) and crystallized simultaneously with the other liquidus minerals nepheline, microcline, aegirine and amphibole. As liquidus phase, EGM monitors the evolution of the bulk melt and convection in the magma chamber.

2. The data demonstrate a systematic stratigraphic variation in major and trace element composition of liquidus EGM in the Lovozero eudialyte complex (Phase III). No abrupt changes are observed in the compositional trends of EGM. The distribution of elements follows an almost linear trend.

3. The seemingly systematic evolution of bulk melt suggests uninterrupted magma chamber scale convection and continued gravitational accumulation of liquidus crystals or crystal mushes in a closed magma chamber as main mechanism for the lithological layering and evolution in Lovozero Phase III. In addition, floatation in convective magma carried extremely small crystals of, e.g., EGM and lamprophyllite to the top and roof of the magma chamber.

4. A marked negative Eu anomaly and low $\mathrm{Sr}$ point to plagioclase fractionation during the evolution of the parental melt of Ilímaussaq and an olivinebasaltic or basanitic parent. In Lovozero, the absence of Eu anomaly and high Sr point to a melanephelinitic parent.

5. Ilímaussaq EGMs show a marked shift in compositional trends especially in late crystallized lujavrites $[8,30]$. The marked changes are suggested due to mixing with residual melts from crystal mushes or the arrival of new phase on liquidus. Alternatively, changes in the partition coefficients would affect the compositions of EGM as would subsequent reaction with intercumulus melts and by re-equilibration processes (e.g., [31,32]).

Author Contributions: The present work is based on L.N.K. and T.F.D.N. and the data therein. The data is in the present manuscript used for comparisons and discussions, aimed to increase the understanding of the petrogenetic systems of eudialyte-bearing peralkaline systems. T.F.D.N. contributes with detail experience in Ilímaussaq and Gardar Province magmatisme (Greenland) backed by recent modeling of the Isortoq Fe-Ti-V deposit and L.N.K. with detailed knowledge on the Lovozero Complex and the petrogenetic systems of the Kola Province. The first draft of the manuscript was prepared by L.N.K., T.F.D.N. subsequently restructured and added interpretation, discussion and conclusions. Both authors have read and agreed to the published version of the manuscript.

Funding: The work was supported by the Grant of the Ministry of Science and Higher Education of the Russian Federation No. 13.1902.21.0018 (Agreement No. 750-15-2020-802) "Fundamental problems of the development of the mineral resource base of high-tech industry and energy in Russia".

Institutional Review Board Statement: Not applicable.

Informed Consent Statement: Not applicable.

Data Availability Statement: Not applicable.

Acknowledgments: We are grateful to Glazatova I.A. from GEOKHI RAS for her help in work with the database on the obtained eudialyte analyses.

Conflicts of Interest: The funders had no role in the design of the study; in the collection, analyses, or interpretation of data; in the writing of the manuscript, or in the decision to publish the results. 


\section{References}

1. Chukanov, N.V.; Aksenov, S.M.; Pekov, I.V.; Belakovskiy, D.I.; Vozchikova, S.A.; Britvin, S.N. Sergevanite, $\mathrm{Na}_{15}\left(\mathrm{Ca}_{3} \mathrm{Mn}_{3}\right)\left(\mathrm{Na}_{2} \mathrm{Fe}_{2} \mathrm{Zr}_{3}\right.$ $\mathrm{Si}_{26} \mathrm{O}_{72}(\mathrm{OH})_{3} \mathrm{H}_{2} \mathrm{O}$, a new eudialyte-group mineral from the Lovozero alkaline massif, Kola Peninsula. Can. Mineral. 2020, 58, 421-436. [CrossRef]

2. Mikhailova, J.A.; Ivanyuk, G.Y.; Kalashnikov, A.O.; Pakhomovsky, Y.A.; Bazai, A.V.; Yakovenchuk, V.N. Petrogenesis of the Eudialyte Complex of the Lovozero Alkaline Massif (Kola Peninsula, Russia). Minerals 2019, 9, 581. [CrossRef]

3. Schilling, J.; Wu, F.-Y.; McCammon, C.; Wenzel, T.; Marks, M.A.W.; Plaff, K.; Jacob, D.E.; Markl, G. The compositional variability of eudialyte-group minerals. Mineral. Mag. 2011, 75, 87-115. [CrossRef]

4. Sjöqvist, A.S.L.; Cornell, D.H.; Andersen, T.; Eramber, M.; Ek, M.; Leijd, M. Three compositional varieties of rare-earth element ore: Eudialyte-group minerals from the Norra Kärr alkaline complex, Southern Sweden. Minerals 2013, 3, 94-120. [CrossRef]

5. Rastsvetaeva, R.K.; Chukanov, N.V. New data on the isomorphism in eudialyte-group minerals. Crystal-chemical mechanisms of blocky isomorphism at the key sites. Minerals 2020, 10, 720. [CrossRef]

6. Gerasimovsky, V.I.; Volkov, V.P.; Kogarko, L.N.; Polyakov, A.I.; Saprykina, T.V.; Balashov, Y.A. The Geochemistry of the Lovozero Alkaline Massif, Part 1. Geology and Petrology. Part 2. Geochemistry; Translation of original Russian text published in 1966; Brown, D.A., Translator; Australian National University Press: Canberra, Australia, 1968; pp. 224, 369.

7. Sorensen, H. Rhythmic igneous layering in peralkaline intrusions: An essay review on Ilímaussaq (Greenland) and Lovozero (Kola, USSR). Lithos 1969, 2, 261-283. [CrossRef]

8. Borst, A.; Friis, H.; Nielsen, T.; Waight, T. Bulk and Mush Melt Evolution in Agpaitic Intrusions: Insights from Compositional Zoning in Eudialyte, Ilfmaussaq Complex, South Greenland. J. Petrol. 2018, 59, 1-23. [CrossRef]

9. Marks, M.A.W.; Eggenkamp, H.G.M.; Atanasova, P.; Mundel, F.; Kümmel, S.; Hagen, M.; Wenzel, T.; Markl, G. Review on the Compositional Variation of Eudialyte-Group Minerals in the Ilímaussaq Complex (South Greenland). Minerals 2020, $10,1011$. [CrossRef]

10. Rastsvetaeva, R.K.; Chukanov, N.V.; Aksenov, S.M. Minerals of Eudialyte Group: Crystal Chemistry, Properties, Genesis; University of Nizhni Novgorod: Nizhniy Novgorod, Russia, 2012; p. 230. ISBN 978-5-91326-207-3. (In Russian)

11. Rastsvetaeva, R.K.; Chukanov, N.V.; Pekov, I.V.; Schafer, C.; Van, K.V. New data on the isomorphism in eudialyte-group minerals. 1. Crystal chemistry of eudialyte-group members with $\mathrm{Na}$ incorporated into the framework as a marker of hyperagpaitic conditions. Minerals 2020, 10, 587. [CrossRef]

12. Johnsen, O.; Grice, J.D.; Gault, R.A. The crystal chemistry of the eudialyte group. Canad. Mineral. 1999, 37, 865-891.

13. Rastsvetaeva, R.K.; Chukanov, N.V. Classification of eudialyte-group minerals. Geol. Ore Depos. 2012, 54, 487-497.

14. Kogarko, L.; Nielsen, T.F.D. Chemical Composition and Petrogenetic Implications of Eudialyte-group mineral in the peralkaline Lovozero Complex, Kola Peninsula, Russia. Minerals 2020, 10, 1036. [CrossRef]

15. Kramm, U.; Kogarko, L.N. Nd and Sr isotope signatures of the Khibina and Lovozero agpaitic centres, Kola alkaline province, Russia. Lithos 1994, 32, 225-242. [CrossRef]

16. Kogarko, L.N.; Lahaye, Y.; Brey, G.P. Plume-related mantle source of super-large rare metal deposits from the Lovozero and Khibiny massifs on the Kola Peninsula, Eastern part of Baltic Shield: Sr, Nd and Hf isotope systematics. Miner. Pet. 2010, 98, 197-208. [CrossRef]

17. Marks, M.; Vennemann, T.; Siebel, W.; Markl, G. Nd-, O-, and H-isotopic evidence for complex, closed-system fluid evolution of the peralkaline Ilimaussaq intrusion, South Greenland. Geochim. Cosmochim. Acta 2004, 68, 3379-3395. [CrossRef]

18. Downes, H.; Balaganskaya, E.; Beard, A.; Liferovich, R.; Demaiffe, D. Petrogenetic processes in the ultramafic, alkaline and carbonatitic magmatism in the Kola Alkaline Province: A review. Lithos 2005, 85, 48-75. [CrossRef]

19. Gerasimovsky, V.I. Geochemie des Ilimaussak—Alkalischen Arrays (Süd-Zap. Grönland); Izdatel'stvo M: Nauka Moscow, Russia, 1969; p. 74. (In Russian)

20. Kogarko, L.N.; Kononova, V.A.; Orlova, M.P.; Woolley, A.R. Alkaline Rocks and Carbonatites of the World, Part 2. Former USSR; Chapman and Hall: London, UK, 1995; 226p.

21. Mikhailova, J.A.; Pakhomovsky, Y.A.; Panikorovskii, T.L.; Bazai, A.V.; Yakovenchuk, V.N. Eudialyte Group Minerals from the Lovozero Alkaline Massif, Russia: Occurrence, Chemical Composition, and Petrogenetic Significance. Minerals 2020, 10, 1070. [CrossRef]

22. Wu, F.-Y.; Yang, Y.-H.; Marks, M.A.W.; Liu, Z.-C.; Zhou, Q.; Ge, W.-C.; Yang, J.-S.; Zhao, Z.-F.; Mitchell, R.H.; Markl, G. In situ $\mathrm{U}-\mathrm{Pb}, \mathrm{Sr}, \mathrm{Nd}$ and $\mathrm{Hf}$ isotopic analysis of eudialyte by LA-(MC)-ICP-MS. Chem. Geol. 2010, 273, 8-34. [CrossRef]

23. Pfaff, K.; Krumrei, T.; Marks, M.; Wenzel, T.; Rudolf, T.; Markl, G. Chemical and physical evolution of the 'lower layered sequence' from the nepheline syenitic Ilímaussaq intrusion, South Greenland: Implications for the origin of magmatic layering in peralkaline felsic liquids. Lithos 2008, 106, 280-296. [CrossRef]

24. Ussing, N.V. Geology of country around Julianehaah. Medd. Grønl. 1911, 38, 1-344.

25. Kogarko, L.N.; Burnham, C.; Shettle, D. Water regime in alkaline magmas. Geochem. Int. 1977, 14, 1-8.

26. Marks, M.A.W.; Markl, G. A global review on agpaitic rocks. Earth Sci. Rev. 2017, 173, 229-258. [CrossRef]

27. Kogarko, L.N.; Williams, C.T.; Woolley, A.R. Chemical evolution and petrogenetic implications of loparite in the layered, agpaitic Lovozero complex, Kola Peninsula, Russia. Mineral. Petrol. 2002, 74, 1-24.

28. Kogarko, L.N.; Romanchev, B.P. Geochemical criteria of ore potential of alkaline magmas. Geochem. Int. 1986, 10, 1423-1430. 
29. Kogarko, L.N. Chemical composition and petrogenetic implications of apatite in the Khibina apatite-nepheline deposits (Kola Peninsula). Minerals 2018, 8, 532. [CrossRef]

30. Marks, M.A.W.; Markl, G. The Ilímaussaq alkaline complex, South Greenland. In Layered Intrusions; Charlier, B., Namur, O., Latypov, R., Tegner, C., Eds.; Springer: Dordrecht, The Netherlands, 2015; pp. 649-691.

31. Henderson, P. Geochemical indicator of the efficiency of fractionation of the Skaergaard Intrusion, East Greenland. Mineral. Mag. 1975, 40, 286-291. [CrossRef]

32. Hunter, R.H. Texture development in cumulate rocks. In Developments in Petrology; Cawthorn, R.G., Ed.; Elsevier: Amsterdam, The Netherlands, 1996; pp. 77-101.

33. Villemant, B.; Jaffrezic, H.; Joron, J.L.; Treuil, M. Distribution Coefficients of Major and Trace-Elements; Fractional Crystallization in the Alkali Basalt Series of Chaine-Des-Puys (Massif Central, France). Geochim. Cosmochim. Acta 1981, 45, 1997-2016. [CrossRef]

34. Nash, W.P.; Crecraft, H.R. Partition coefficients for trace elements in silicic magmas. Geochim. Cosmochim. Acta 1985, 49, 2309-2322. [CrossRef]

35. Nielsen, R.L. A method for the compositional dependence of trace element distribution coefficients. Geochem. Cosmochem. Acta 1985, 49, 1775-1779. [CrossRef]

36. Larsen, L.M. Aenigmatites from the Ilímaussaq intrusion, South Greenland: Chemistry and petrological implications. Lithos 1977, 10, 257-270. [CrossRef]

37. Kogarko, L.N. The principle of chemical bond polarity in the geochemistry of magmatism. Geochemistry 1980, 9, $1286-1297$.

38. Cicconi, M.R.; de Ligny, D.; Gall, T.M.; Neuvill, D.R. Ca neighbors from XANES spectroscopy: A tool to investigate structure, redox, and nucleation processes in silicate glasses, melts, and crystals. Am. Mineral. 2016, 101, 1232-1235. [CrossRef]

39. Larsen, L.M.; Sørensen, H. The Ilimaussaq intrusion-progressive crystallization and formation of layering in an agpaitic magma. In Alkaline Igneous Rocks; Fitton, J.G., Upton, B.G.J., Eds.; Geological Society of London, Special Publication: London, UK, 1987; Volume 30, pp. 473-488.

40. Marks, M.A.W.; Hettmann, K.; Schilling, J.; Frost, B.R.; Markl, G. The mineralogical diversity of alkaline igneous rocks: Critical factors for the transition from miaskitic to agpaitic phase assemblages. J. Petrol. 2011, 52, 439-455. [CrossRef]

41. Upton, B.G.J. Tectono-magmatic evolution of the younger Gardar southern rift, South Greenland. Geol. Surv. Den. Greenl. Bull. 2013, 29, 1-128. [CrossRef]

42. Bartels, A.; Nielsen, T.F.D.; Lee, S.R.; Upton, B. Petrological and geochemical characteristics of Mesoproterozoic dyke swarms in the Gardar Province, South Greenland: Evidence for a major sub-continental lithospheric mantle component in the generation of the magmas. Mineral. Mag. 2015, 79, 909-939. [CrossRef] 